\title{
Editorial
}

\section{An Islamic Perspective of Assisted Reproductive Technologies}

Nordin MM

\section{Introduction}

Dr. Edwards, an embryologist and Dr. Steptoe, a gynaecologist in the United Kingdom first pioneered the fertility technique called In Vitro Fertilisation Pre-Embryo Transfer ( IVF - ET ). In July 1978, they announced to the world the birth of the first test-tube baby, Louise Brown which was a landmark achievement in the science of reproductive medicine ${ }^{1}$.

Since then, a myriad of assisted reproductive techniques have surfaced, further refining and superseding earlier technologies. Assisted reproductive technologies (ART) refers to all the techniques involved in the management of infertility that require the handling and manipulation of gametes and embryos and treatment modalities to induce ovulation or spermatogenesis. Techniques of invivo assisted reproduction facilitate the fertilization of the gametes within the reproductive tract of the wife. This may be achieved through the procedures of intrauterine insemination (IUI), intratubal insemination (ITI) and gamete intra fallopian transfer ( GIFT) ${ }^{2}$. Mating of the gametes ocuur extracorporeally during invitro assisted conception. The modalities to facilitate the fertilization invitro followed by transfer into the reproductive tract include in vitro fertilisation and embryo transfer (IVF - ET), pronuclear stage tubal transfer (PROST), zygote intrafallopian transfer (ZIFT) and tubal embryo stage transfer (TEST) $)^{3,4,5}$. More radical forms of micro-manipulation techniques have been recently developed to assist fertilization of men with severe infertility. These include intracytoplasmic sperm injection (ICSI) and micro injection of round spermatid nuclei into oocytes $(\mathrm{ROSNI})^{6,7}$.

Since the introduction of IVF-ET technology, well over 500,000 babies have been born. The probability of a successful pregnancy is dependant on a variety of factors including the age and the reproductive health of the wife and the husband.
Eventhough reported success rates from ART programs can be very confusing and misleading, the probability of a successful outcome has improved from virtually zero to $30-50 \%$ at ART centers worldwide.

These new technologies in assisted reproduction has provoked considerable discussions and debates across all segments of human society. These revolutionary procedures in ART has probed the outermost boundaries of what is scientifically possible and acceptable. Micro manipulation at the very earliest stages of human development is a very delicate and sensitive issue with potentially explosive ethical, social, medico-legal and religious ramifications. Hence the turbulent and not uncommonly hostile controversies that has since evolved.

The Islamic Organisation for Medical Sciences (IOMS), first addressed this issue on human reproduction in May 1983. Human reproductive cloning, an offshoot of ART, which is currently attracting a lot of public and media attention was similarly addressed at this 1983 seminar. Since the IOMS seminar, there has been a multitude of medicoIslamic jurisprudence seminars to discuss various contemporary issues related to ART.

This essay attempts to examine the various bioethical facets of ART and present an Islamic perspective of the infertility problem and the bio-religio-ethics of ART.

\section{Infertility In The Quran}

There are a few case scenarios depicted in the $\mathrm{Al}$ Quran which helps us to gain a proper insight into the problem of infertility.

The first illustrates the story of Ibrahim SAW and his wife Sara as revealed in Surah $51: 28-30$.

"...And they (angels) gave him (Ibrahim) glad tidings of a son endowed with knowledge. But his wife 
came forward clamouring, she smote her forehead and said; "A barren old woman!" They said, "Even so has thy Lord spoken and He is full of wisdom and knowledge."

The aged Sara had willingly resigned to her destiny of being infertile but yet continued to be firm in her faith and true to her husband. She remained a complete, faithful woman in every other way. And she offered Hajar to Ibrahim SAW in marriage, so as to enable him to have children. She was ultimately blessed with a child, Ishaq SAW.

As with the example of Ibrahim SAW, Zakaria SAW remained faithful and supportive of his infertile wife. In surah 21 : 89-90, Allah says :

"And (remember) Zakaria, when he cried to his Lord: "O my Lord! Leave me not without offspring, though Thou are the best of inheritors." So we listened to him and granted him Yahya. We cured his wife (barrenness) for him. These three were ever quick in emulation in good works; they used to call on Us with love and reverence, and humble themselves before us."

Being infertile does not make one any lesser a man or woman. Like Zakaria SAW, one should beseech Allah for the blessings of offsprings. We pray and hope our children to perpetuate our family lineage and to continue to disseminate the teachings of God's chosen prophets. The example of the earlier prophets and their wives teaches one to pray to God and endeavour to rectify the infertility disorder but if one is unsuccessful then one accepts the predestination ordained as Allah has clearly decreed in surah 42: 49-40

"To Allah belongs the dominion of the heavens and the earth. He creates what He wills. He bestows (children) male or female according to His will. Or He bestows both males and females, and He leaves barren whom He wills; for he is full of knowledge and power."

If the earlier two examples ended with the successful outcome of an offsrping, the final scenario narrates the story of Asiya who never consummated her marriage to Pharaoh. She remained childless till her martyrdom but she nurtured a prophet, Musa SAW, right from his infancy. Asiya, though childless, remained full of faith and potrayed a shining example of faith and fortitude to all believing woman when struck with a similar predicament. Allah says in surah 66:11;

"And Allah sets forth, as an example to those who believe the wife of Pharaoh : Behold she said : O my Lord! Build for me, in nearness to Thee, a mansion in the Garden, and save me from Pharaoh and his doings, and save me from those that do wrong."

\section{Inffrtility In The Hadth}

Suffice it to quote two very instructive sayings of the Propeht SAW which would have a very significant impact on our handling of the infertility issue.

"Marry women who will love you and give birth to many children for I shall take pride in the great numbers of my ummah" (Sunan al Nasai)

In his deliverance of the message of Islam, the Prophet SAW produced a generation of Muslims who were torch bearers of the true teachings of AlQuran, who has since been decorated with the accolade of the unique Quranic generation. And in this hadith he emphasized the importance of the large numbers of his ummah. Besides quality of the believers, quantity is similarly an important denominator.

A pivotal principle taught by the prophet vis a vis medicine and reproductive medicine is no exception is contained in the following hadith reported by Sahih Muslim;

\section{"For every disease there is a cure"}

Infertility has been recognized by the World Health Organisation as a disease with significant mental and psychological morbidity. And quite clearly, the Muslims have been exhorted to explore the various curative strategies to overcome this disease which afflict up to $15 \%$ of couples.

\section{Epidemiology of Infertility In The Muslim World}

The reported population of Muslims in 1992 was 1.25 billion 8 . This statistic is expected to double in 2020. Up to 80 million of the world population are affected by some form of infertility problem. And Muslims contribute up to $40-50 \%$ of the infertile couples. The rate of infertility is relatively higher in 
the Muslim world when compared to the developed west. A WHO report have shown that the rate of tubal occlusion in Muslim sub Saharan Africa was well over three times that of other regions with the exception of the Eastern Mediterranean 9. The patterns of male infertility is however less apparent but regional variation in varicocoele and other related condition have been reported.

\section{Bio-religio-ethics of Assisted Reproductive Technologies In The Muslim World}

The teachings of the Quran and Hadiths have emphasized the vital role of the institution of marriage and the family structure. And inseparable from this is the act of procreation. To this effect Allah SWT says in surah 16 :72;

"And Allah has given you wives of your own kind, and has given you, from your wives, sons and grandsons, and has made provisions of good things for you. Is it then in vanity that they believe and in the grace of Allah that they disbelieve?"

It therefore follows that the prevention and treatment of infertility is encouraged and becomes a medical priority because it will ensure an uninterrupted process of procreation 10. Islam enjoins the affected man and woman to seek medical treatment including contemporary ART, to fulfill their cherished hope of parenthood.

Since marriage and purity of lineage is fundamental in the teachings of Islam, it is very important that this unadulterated inheritance of genes and heredity is preserved. Any method of ART practised must therefore guard against any mixing of the genes. Every newborn child must relate unequivocally to a biological and legal father and mother. Hence the premise to the practice of any modality of ART is to abide by the Shariah system of legally binding marriage through the union of the sperm and the ovum.

\section{Assisted Reproductive Tecnologies - The Islamic Paradigm}

The Islamic Organisation for Medical Sciences (IOMS) first addressed this issue of assisted reproduction in their Fiqh Medical Seminar in May 1983. The IOMS seminar are always well attended by distinguished jurists, shariah experts, medical practitioners, scientists and specialists in other human sci- ences. Based on the conclusions of the Fiqh Medical Seminar of the IOMS and the opinions of other medical-shariah authorities in this area of ART, I have summarized the fundamental ground rules which must be adhered to diligently by any Muslim practitioner of ART.

1. The sanctity of the marital contract must not be violated at any point in time during the ART process. The Muslim practitioner of ART must guard jealously the purity and legality of the sperm and ovum of the couple. Since the union of the sperm and ovum is occurring one step beyond the act of sexual coitus, the fusion must take place within the jurisdiction of a marriage contract ${ }^{11}$.

2. The dyad of the legal husband and wife must not be intruded by any third party. The involvement of a third person in the equation is totally unacceptable whether this take the form of a sperm, an ovum, an embryo or a uterus. Hence the widespread practice in ART facilities of sperm, ovum and embryo donation and the "rental" of uterus is incompatible with the Islamic injunctions related to human reproduction ${ }^{11}$.

3. Once the marital contract has been terminated either due to divorce or death of the husband, assisted reproduction cannot be performed on the ex-wife or widow using sperm cells from the former or dead husband or using the previously cryopreserved embryos of the couple. The stored semen and cryopreserved embryo of her ex or dead husband now becomes alien to her and the latter to either party ${ }^{12}$.

4. In ART programs, the excess pre-embryos produced can be frozen and stored in liquid nitrogen, a technique called cryopreservation. This can only be undertaken after the free informed consent of the couple is obtained. The excess pre-embryos continues to remain the property of the couple. It can only be transferred to the uterus of the wife and only during the validity of the marriage contract ${ }^{13}$.

5. Cryopreservation should only be allowed in specially designated sperm and pre-embryo banks or ART centres accredited by the relevant health authorities. An accurate and full proof system of documentation must be in place to guard against mixing of lineages and commercialism. Confidentiality of information should not be breached and tight security procedures should prevent unauthorized access to records ${ }^{14}$. 
6. Credentialling of all staff participating in the ART program is of utmost importance to ensure the highest standards of professionalism, trustworthiness, integrity and responsibility. Strict adherence to evidence based reproductive medicine, clinical practice guidelines and a code of ethical ART practice by all related professionals would help to protect the infertile couple who are often very desperate, emotional and hence very vulnerable to the unethical and profit driven ART practitioner. Hence the latter three qualities of trustworthiness, integrity and responsibility often supersede the string of professional qualifications ${ }^{15}$.

7. Many countries have now restricted the numbers of eggs or embryos which could be placed in a woman in any one cycle. The recommended clinical guideline in Malaysia is that no more than 3 eggs or embryos can be implanted into a woman in any one cycle. However, up to a maximum of 4 eggs or embryos maybe transferred if two conditions are met; firstly, the patient has undergone no less than 2 ART attempts which were unsuccessful and secondly, the patient is between 35-45 years of age. If the procedures of stimulating and monitoring egg production are closely monitored and the numbers of embryos implanted are restricted, then the likelihood of generating excessive multifoetal gestation would be minimized. However, if despite this, in excess of three foetuses are gestated, pregnancy reduction is permissible if the prospect of foetal viability is compromised or if the health or life of the mother is threatened. Multiple pregnancy of an order higher than twins presents an increased health hazard to the gravid mother and also for her fetuses which are more likely to be spontaneously aborted or to be delivered extremely prematurely with all the attendant complications of prematurity ${ }^{16}$.

8. The abuse of infertility procedures maybe prevented and other related activities of ART maybe better monitored through acts of legislation. The Human Fertilisation and Embryology Act 1990 in the United Kingdom and Eire was an act of parliament which among others made provisions in connection with human embryos and any subsequent development of such embryos and to prohibit certain practices in connection with embryos and gametes ${ }^{17}$. The Ministry of Health is now at the stage of drafting laws to address the activities of ART in Malaysia.
9. There are various permutations of surrogate motherhood. In the first form, the surrogate is impregnated with the commissioning husband's semen; carry the pregnancy to term and give away the baby to the commissioning couple. The commissioning couple may via IVF transfer their resultant embryo to the surrogate mother. They therefore remain the biological parents. Or the surrogate may be impregnated with donated semen or embryo and reared by the commissioning parents. In this last case scenario, there will arise 3 set of parents; the rearing parents, biological parents and surrogate mother. A case was brought up in the legal courts recently about the parentage of a surrogate child. Five individuals laid claim to the child. And the court ruled that none had legal parental claims to the child !Surrogacy in all its forms is not allowed in Islam ${ }^{18}$.

\section{Pre-implantation Genetic Diagnosis (Pgd)}

Two hadiths related from the Prophet SAW has helped us to have a better insight into the science of genetics.

"Select your spouses carefully in the interest of your offspring because lineage is a crucial issue"

"Do not marry your close relatives because you will beget weak offsrpings"

The second Caliph of Islam, Omar ibn El-Khattab, upon noting that a particular tribe intermarried with increased frequency, remarked to them :

"You have weakened your descendants. You should marry strangers (people outside your tribe)".

The spirit of the exhortations of the Prophet SAW and his companion was to secure normal and healthy babies, protection of their early well being, endowed with the benefits of good genes from both parents and the prevention of congenital malformations and its consequent disabilities.

A variety of inherited diseases may now be diagnosed in the pre-embryo stage prior to implantation into the uterus. Highly sensitive polymerase chain reaction (PCR) techniques have enabled the rapid amplification of minute amounts of DNA material from the embryonic cells. Fluorescent in situ 
hybridization (FISH) technology with combination chromosomal probes have made possible the genetic analysis of embryonal sex and various aneuploidies ${ }^{19}$.

Some of the potentially debilitating diseases which may be screened include Trisomy ${ }^{13,17-21}$, cystic fibrosis, haemophilia, Marfan's syndrome, incontinentia pigmentosa, $\mathrm{x}$-linked immune deficiency, retinitis pigmentosa, fragile $\mathrm{X}$ syndrome, muscular dystrophy and Lesch-Nyhan disease. It is postulated that well over 200 diseases or conditions can be further isolated with ongoing PGD research ${ }^{20}$.

The First International Conference on Bioethics in the Muslim World held in Cairo from ${ }^{10-13}$ Dec 1991 examined very carefully this area of pre-embryo research $^{21}$. Collaborating this with the decisions of other scientific cum Islamic jurisprudence seminars, the following practice guidelines may be summarized :

1. Cryopreserved pre-embryos may be used for research purposes with the free and informed consent of the couple.

2. Research conducted on pre-embryos is limited only to therapeutic research. Genetic analysis of pre-embryos to detect specific genetic disorders is permissible. Hence diagnostic aids should be provided for couples at high risk for selected inherited diseases. The treated embryo may only be implanted into the uterus of the wife who is the owner of the ova and only during the span of the marriage contract.

3. Any pre-embryos found to be genetically defective maybe rejected from transfer into the uterus after proper counselling by the physician.

4. Research aimed at changing the inherited characteristics of pre-embryos ( e.g. hair and eye colour, intelligence, height ) including sex selection is forbidden.

5. Sex selection is however permitted if a particular sex predisposes to a serious genetic condition. One of the first couple to use this technique of sex selection was hoping to escape a deadly disease known as $\mathrm{x}$-linked hydro- cephalus, which almost always affected boys. Embryonal sex selection would make possible the weeding out of other serious $\mathrm{x}$-linked disorders including haemophilia, Duchenne muscular dystrophy and fragile $\mathrm{X}$ syndrome.

6. The free informed consent of the couple should be obtained prior to conducting any non-therapeutic research on the pre-embryos. These preembryos should not be implanted into the uterus of the wife or that of any other woman.

7. Research of a commercial nature or not related to the health of the mother or child is not allowed.

8. The research should be undertaken in accredited and reputable research facilities. The medical justification for the research proposal must be sound and scientific and conducted by a skilled and responsible researcher.

\section{Conclusions}

Contemporary technology in the realm of assisted reproduction has been a major breakthrough in the management of infertility. Undoubtedly, it has brought great joy and happiness to many previously infertile couples.

Along with it, ART has created her own set of bioreligio- ethical problems and dilemmas. The response to this new technique in human reproduction has ranged from categorical condemnation by the Roman Catholic Church to the multiple reproductive permutations of the libertarian philosophy.

It is interesting to note that in this very difficult, painful and emotional issue Islam has presented a middle of the road solution, moderating between the two extreme views. Allah says in surah $2: 143$;

"Thus we have appointed you a middle nation, that you may be witness against mankind, and that the messenger may be witness against you ..."

ART is Islamically acceptable and commendable provided it is practised within the husband and wife dyad during the span of the marital contract ${ }^{22}$. 


\section{References}

1. Steptoe PC, Edwards RG. Birth after the reimplantation of a human embryo. Lancet 1978;2:366 http://dx.doi.org/10.1016/S01406736(78)92957-4

2. Asch RH, et al. Birth following gamete intrafallopian transfer. Lancet 1985;2:163 http://dx.doi.org/10.1016/S0140$\underline{\text { 6736(85)90274-0 }}$

3. Yovich JL, et al. treatment of male infertility by invitro fertilization. Lancet 1984;2:169-170 http://dx.doi.org/10.1016/S0140$\underline{6736(84) 91088-2}$

4. Yovich JL, et al. Pregnancy afet translaparoscopic zygote intrafallopian transfer in a patient with sperm antibodies. Lancet 1986;1:1329

5. Yovich JL, et al. The relative chance of pregnancy following tubal or uterine transfer procedures. Fertility and sterility 1988;49:858-864 PMid:3360175

6. Van Steirteghem, et al. High fertilization and implantation rates after intracytoplasmic sperm injection. Human Reproduction 8:1061-1066 PMid:8408487

7. Sofikitis N, et al. Human pregnancies achieved by intra-ooplasmic injections of round spermatid nuclei isolated from testicular tissue of azoospermic men. Las Vegas, Nevada:AUA meeting Abstracts/PRISM Production, 0616

8. Serour GI, et al. Infertility : A health problem in Muslim world. Population Sciences. IICPSR 1991;10:41-58

9. Report of a WHO Scientific Group. Recent advances in medically assisted conception. WHO technical report series 820. Geneva 1992.

10. Jad al-Haq 'Ali Jad al-Haq (HE) Dar al-Ifta', Cairo, Egypt 1225 1980; 1;115: 3213-3228
11. Fedel HE. Assisted reproductive technologies An Islamic perspective. Journal Islamic Medical Association. 1953; 25: 14-19

12. Serour GI, et al. Invitro fertilization and embryo transfer ethical aspects in techniques in the Muslim world. Population Sciences IICPSR 1990; 9:45-53

13. Serour GI, Omran AR. Ethical guidelines for human reproduction research in the Muslim world. IICPSR 1992; 29-31

14. Aly A Mishal. Cloning and advances in molecular biotechnology : Islamic Shariah guidelines. FIMA 2002; 33-47

15. Consensus Workshop on Assisted Reproductive Technologies; Hospital Kuala Lumpur, Oct 1997

16. Musa MN, et al. Outcome of extremely premature infants in Damansara Specialist Hospital 1998-2000. KPJ Medical Digest 2002; 9-12.

17. Human Fertlilisation and Embryology Act 1990; Chapter 37

18. Pertowmah M. Surrogacy issues in the opinion of Islamic scholars. Journal Islamic Medical Association 1993; 25 : 9-13

19. Grifo JA,et al. Update in preimplantation diagnosis. Advances and problems. Current Opinions Obstet Gynae 8:135-138

20. Fact Sheet : Preimplantation Genetic Diagnosis. American Society for Reproductive Medicine. Dec 1996

21. Serour GI. Proceeding to the 1st international congress on bioethics in human reproduction research in the Muslim world. IICPSR $1992 ; 2$

22. Musa MN. Human genetic and reproductive technologies - an internatoal medico-legal- religious impasse? Bangladesh Journal of Medical Science 2011; 10(01): 001-011. DOI: 10.3329/bjms.v10i1.7311 